\title{
PEMADATAN LAPANGAN ASPHALT CONCRETE BINDER COURSE $(A C-B C)$ PADA PEMBANGUNAN JALAN SIMPANG KARYA MUKTI KABUPATEN BATANGHARI
}

\author{
Siswoyo, Fakhrul Rozi Yamali \\ Program Studi Teknik Sipil Unbari Jambi \\ fakhrul_65@yahoo.co.id
}

\begin{abstract}
Abstrak
Pembangunan Jalan Simpang Karya Mukti Kabupaten Batanghari sepanjang 3,70 $\mathrm{km}$ yang terdiri dari Lapis Pondasi Tanah Semen (SCB), Lapis Asphalt Concrete Binder Course (AC-BC), Lapis Asphalt Concrete Wearing Course (AC-WC). Tujuan penelitian ini untuk ; 1.Menghitung koefisien pemadatan (factor gembur) hamparan Asphalt Concrete Binder Course (AC-BC) dilapangan, 2. Mengetahui jumlah passing / lintasan dan temperatur serta jenis alat yang dipakai pada pemadatan awal, pemadatan antara dan pemadatan akhir, 3. Mendapatkan tebal padat Asphalt Concrete Binder Course (AC-BC) $\geq 6.00 \mathrm{Cm}$ (tebal nominal) dan nilai derajat kepadatan minimal $98 \%$ sebagai identifikasi pengendalian mutu pekerjaan yang dilaksanakan. Hasil pembahasan didapat Nilai koefisien pemadatan (faktor gembur) hamparan dilapangan Asphalt Concrete Binder Course (AC-BC) adalah $20 \%$ dari tebal padat $6 \mathrm{Cm}=1.20 \mathrm{Cm}$, maka total hamparan gembur 6.00 $\mathrm{Cm}+1.20 \mathrm{Cm}=7.20 \mathrm{Cm}$, 2). Jumlah passing/lintasan dan temperatur serta jenis alat yang dipakai pada pemadatan awal, pemadatan antara dan pemadatan akhir adalah berpedoman pada percobaan variasi II yaitu pemadatan awal 2 passing Tandem Roller $\left(8\right.$ Ton) dengan suhu $125^{\circ} \mathrm{C}$, pemadatan antara 14 passing Pneumatic Tire Roller(12 Ton) dengan suhu $100^{\circ} \mathrm{C}$ dan pemadatan akhir 2 passing Tandem Roller ( 8 Ton) dengan suhu $95^{\circ} \mathrm{C}$, 3). Setelah dilakukan core tebal yang didapat adalah $6.05 \mathrm{Cm}>6.00 \mathrm{Cm}$ dan nilai derajat kepadatan adalah $99.89 \%>89.00 \%$.
\end{abstract}

Kata kunci: AC-BC, Hot Bin, Koefisien Pemadatan

\section{PENDAHULUAN}

Pembangunan transportasi khususnya pembangunan jalan dewasa ini di Indonesia merupakan prioritas pemerintah dalam rangka menjangkau wilayah NKRI yang cukup luas. Provinsi merupakan salah satu provinsi yang terus menggeliat dalam dalam pembangunan jalan. Jalan sebagai prasarana distribusi barang dan jasa merupakan urat nadi kehidupan masyarakat, bangsa, dan Negara. Jalan sebagai bagian prasarana transportasi mempunyai peran penting dalam bidang ekonomi, sosial budaya, lingkungan hidup, politik, pertahanan dan keamanan, serta dipergunakan untuk sebesar-besar kemakmuran rakyat. Kemajuan pembangunan suatu wilayah terlihat dengan peningkatan pembangunan jalan yang bisa menghubungkan daerah-daerah terpencil menjadi lebih maju dan hal ini terlihat dari banyaknya pembangunan jalan sebagai akses transfortasi darat.

Kecamatan Maro Sebo Ilir Kabupaten Batanghari, di kawasan ini terdapat lahan potensial yang cukup luas untuk dikembangkan di bidang agribisnis maupun agroindustri dan jenis komoditas yang potensial sedang dikembangkan di kawasan ini yaitu karet dan kelapa sawit. Dinas Pekerjaan Umum Kabupaten Batanghari melalui Sumber Dana Alokasi Khusus (DAK) Kabupaten Batanghari Tahun 2016.Membangun Jalan Simpang Karya Mukti Kabupaten Batanghari sepanjang $3,70 \mathrm{~km}$ yang salah satu konstruksinya adalah Lapis Asphalt Concrete Binder 
Course (AC-BC) dengan lebar 5 meter.Agar pembangunan jalan yang dilaksanakan mencapai sasaran yang diinginkan sesuai persyaratan Spesifikasi Umum Bina Marga 2010 (Revisi 3), maka dalam pelaksanaan pekerjaannya harus : 1). Tepat mutu, 2). Tepat waktu dan 3).Tepat biaya.Untuk mencapai Tepat mutu, pengendalian pemadatan lapis perkerasan aspal yang digelar di lapangan merupakan hal yang sangat penting. Karena kepadatan lapis perkerasan aspal yang kurang memadai akan menyebabkan stabilitasnya menurun dan rongga dalam campuran menjadi besar sehingga lapis perkerasan aspal tidak kedap air yang akan berakibat nilai struktur lapis perkerasan aspal menjadi berkurang dan bias menimbulkan terjadinya kerusakan dini pada lapis perkerasan aspal tersebut, bahkan akan menyebabkan kerusakan pada lapis perkerasan dibawahnya.

Mengacu pada uraian diatas, maka perumusan masalah yang akan dibahas dalam penelitian ini adalah bagaimana tahapan pengesahan Formula Campuran Rencana (FCR) menjadi Formula campuran Kerja (FCK) sebagai pedoman pelaksanaan pengendalian mutu pemadatan lapangan Asphalt Concrete Binder Course (AC-BC) pada kegiatan Pembangunan Jalan Simpang Karya Mukti Kabupaten Batanghari. Penelitian ini bertujuan untuk:

1. Menghitung koefisien pemadatan (factor gembur) hamparan Asphalt Concrete Binder Course (AC-BC) dilapangan.

2. Mengetahui jumlah passing / lintasan dan temperatur serta jenis alat yang dipakai pada pemadatan awal, pemadatan antara dan pemadatan akhir.

3. Mendapatkan tebal padat Asphalt Concrete Binder Course (AC-BC) $\geq 6.00 \mathrm{Cm}$ (tebal nominal) dan nilai derajat kepadatan minimal 98\% sebagai identifikasi pengendalian mutu pekerjaan yang dilaksanakan.

Dengan permasalahan pemadatan lapangan Asphalt Concrete Binder Course (AC-BC) yang sangat luas dan komplek, maka penulis membatasi dalam peninjauan sebagai berikut:

1. Menghitung koefisien pemadatan untuk menentukan tebal gembur hamparan Asphalt Concrete Binder Course (AC-BC) di lapangan.

2. Uji coba pemadatan di lapangan (Trial Density) untuk menentukan jumlah passing / lintasan pemadatan.

3. Menghitung derajat kepadatan dengan membandingkan kepadatan lapangan dengan kepadatan laboratorium dikalikan $100 \%$ mengacu pada Spesifikasi Umum Bina Marga 2010 (Revisi 3).

\section{TINJAUAN PUSTAKA}

\section{Lapis Aspal Beton (Asphalt Concrete, AC)}

Lapis perkerasan Asphalt Concrete - Binder Course (AC-BC) adalah bagian dari lapis aspal beton pada konstruksi jalan yang terdiri dari campuran aspal keras dan agregat, dicampur dan dihampar dalam keadaan panas serta dipadatkan pada suhu tertentu (Silvia Sukirman, 1999).Ciri lainnya adalah memiliki sedikit rongga dalam struktur agregatnya, saling mengunci satu dengan yang lainnya, oleh karena itu aspal beton memiliki sifat stabilitas tinggi dan relatif kaku.Pembuatan Lapis Aspal Beton (Laston) dimaksudkan untuk mendapatkan suatu lapisan permukaan atau lapis antara pada perkerasan jalan raya yang mampu memberikan sumbangan daya dukung yang terukur serta berfungsi sebagai lapisan kedap air yang dapat melindungi konstruksi dibawahnya. Sebagai lapisan permukaan, Lapis Aspal Beton harus dapat memberikan kenyamanan dan keamanan yang tinggi. 
Pemadatan Lapangan Asphalt Concrete Binder Course (AC-BC) pada Pembangunan Jalan Simpang Karya Mukti Kabupaten Batanghari

Tabel 1. Persyaratan Sifat-Sifat Campuran Lapis Aspal Beton (Laston)

\begin{tabular}{|c|c|c|c|c|}
\hline \multirow[b]{2}{*}{ Sifat-sifat Campuran } & & \multicolumn{3}{|c|}{ LASTON } \\
\hline & & Lapis Aus & $\begin{array}{c}\text { Lapis } \\
\text { Antara }\end{array}$ & Pondasi \\
\hline $\begin{array}{c}\text { Jumlah Tumbukan per } \\
\text { Bidang }\end{array}$ & & \multicolumn{2}{|l|}{75} & 112 \\
\hline \multirow{2}{*}{$\begin{array}{c}\text { Rasio partikel lolos } \\
\text { 0,075mm dengan kadar aspal } \\
\text { efektif }\end{array}$} & Min & & 1,0 & \\
\hline & Maks & & 1,4 & \\
\hline \multirow{2}{*}{$\begin{array}{l}\text { Rongga dalam Campuran } \\
\qquad(\%)\end{array}$} & Min & & 3,0 & \\
\hline & Maks & & 5,0 & \\
\hline Rongga dalam Agregat (\%) & Min & 15 & 14 & 13 \\
\hline Rongga Terisi Aspal (\%) & Min & 65 & 65 & 65 \\
\hline Stabilitas Marshall (kg) & Min & \multicolumn{2}{|c|}{800} & 1800 \\
\hline \multirow{2}{*}{ Pelelehan (mm) } & Min & \multirow{2}{*}{\multicolumn{2}{|c|}{$\begin{array}{l}2 \\
4\end{array}$}} & 3 \\
\hline & Maks & & & 6 \\
\hline $\begin{array}{c}\text { Stabilitas Marshall Sisa } \\
\text { setelah Perendaman } 24 \text { jam, } \\
60^{\circ} \mathrm{C}(\%)\end{array}$ & Min & & 90 & \\
\hline $\begin{array}{l}\text { Rongga dalam Campuran } \\
\text { pada Kepadatan Membal (\%) }\end{array}$ & Min & & 2 & \\
\hline
\end{tabular}

Sumber : Spesifikasi Umum Bina Marga 2010 (Revisi 3)

Agregat

Menurut Silvia Sukirman, 2003 dalam FR Yamali, 2013. Agregat didefinisikan secara umum sebagai formasi kulit bumi yang keras dan padat. Agregat merupakan komponen utama dari struktur perkerasan jalan, yaitu 90\%95\% agregat berdasarkan persentase berat atau 75\%-85\% berdasarkan persentase volume. Dengan demikian kualitas perkerasan jalan ditentukan juga dari sifat agregat dan hasil campuran agregat dengan material lain.

\section{Jenis Agregat Berdasarkan Proses Terjadinya}

Berdasarkan proses terjadinya agregat atas agregat beku (igneous rock), agregat sediment (sedimentary rock) dan agregat metamorfik (metamorphic rock). Jenis Agregat Berdasarkan Ukuran Butir. Berdasarkan ukuran butirnya agregat dapat dibedakan atas agregat kasar, agregat halus dan bahan pengisi (filler). Batasan dari masing-masing agregat ini seringkali berbeda, sesuai institusi yang menentukannya.

\section{Jenis Agregat Berdasarkan Ukuran Butir}

Berdasarkan ukuran butirnya agregat dapat dibedakan atas agregat kasar, agregat halus dan bahan pengisi (filler). Bina Marga, 2005 dalam FR Yamali, 2013, Batasan dari masing-masing agregat ini seringkali berbeda, sesuai institusi yang menentukannya.

1. Agregat kasar adalah agregat dengan ukuran butir lebih besar dari saringan No.8 $(=2,36 \mathrm{~mm})$

2. Agregat halus adalah agregat dengan ukuran butir lebih halus dari saringan No.8 $(=2,36 \mathrm{~mm})$ 
3. Bahan pengisi (filler) adalah bagian dari agregat halus yang lolos saringan No. $30(=0,60 \mathrm{~mm})$

Fraksi agregat kasar untuk rancangan campuran adalah yang tertahan ayakan No.8 (2,36 mm) yang dilakukan secara basah dan harus bersih, keras, awet, dan bebas dari lempung atau bahan yang tidak dikehendaki lainnya dan memenuhi ketentuan. Agregat yang digunakan dalam perkerasan jalan ini adalah agregat yang memiliki diameter agregat antara $2,36 \mathrm{~mm}$ sampai $25 \mathrm{~mm}$.

Tabel 2. Persyaratan Agregat Kasar

\begin{tabular}{|c|c|c|c|c|}
\hline \multicolumn{3}{|c|}{ Pengujian } & Standar & Nilai \\
\hline \multicolumn{2}{|c|}{$\begin{array}{l}\text { Kekekalan bentuk agregat } \\
\text { terhadap larutan }\end{array}$} & $\begin{array}{l}\text { Natrium sulfat } \\
\text { Magnesium } \\
\text { sulfat }\end{array}$ & SNI 3407-2008 & $\begin{array}{l}\text { Maks. } 12 \% \\
\text { Maks. } 18 \%\end{array}$ \\
\hline $\begin{array}{c}\text { Abrasi } \\
\text { dengan } \\
\text { mesin Los } \\
\text { Angeles }\end{array}$ & $\begin{array}{c}\text { Campuran AC } \\
\text { Modifikasi } \\
\text { Semua Campuran } \\
\text { Aspal bergadasi }\end{array}$ & $\begin{array}{l}100 \text { putaran } \\
500 \text { putaran } \\
100 \text { putaran } \\
500 \text { putaran }\end{array}$ & SNI 2417-2008 & $\begin{array}{l}\text { Maks. } 6 \% \\
\text { Maks. } 30 \% \\
\text { Maks. } 8 \% \\
\text { Maks. } 40 \%\end{array}$ \\
\hline \multicolumn{3}{|c|}{ Kelekatan Agregat terhadap Aspal } & SNI 2439-2011 & Maks. $95 \%$ \\
\hline \multicolumn{3}{|c|}{ Butir Pecah pada Agregat Kasar } & SNI 7619-2012 & $95 / 90 *)$ \\
\hline \multicolumn{3}{|c|}{ Partikel Pipih dan Lonjong } & $\begin{array}{c}\text { ASTM D4791 } \\
\text { Perbandingan } \\
1: 5\end{array}$ & Maks. $10 \%$ \\
\hline \multicolumn{3}{|c|}{ Material lolos Ayakan No. 200} & $\begin{array}{c}\text { SNI 03-4142 } \\
1996\end{array}$ & Maks. $2 \%$ \\
\hline
\end{tabular}

Catatan : *) 95/90 menunjukkan bahwa 95\% agregat kasar mempunyai muka bidang pecah atau lebih dan $90 \%$ agregat kasar mempunyai muka bidang pecah dua atau lebih.

Sumber : Spesifikasi Umum Bina Marga 2010 (Revisi 3)

Agregat halus adalah material yang lolos saringan no.8 $(2,36 \mathrm{~mm})$ dan tertahan saringan no.200 $(0,075 \mathrm{~mm})$. Fungsi agregat halus adalah sebagai berikut:

Menambah stabilitas dari campuran dengan memperkokoh sifat saling mengunci dari agregat kasar dan juga untuk mengurangi rongga udara agregat kasar.

1. Agregat halus pada ayakan no 8 sampai ayakan no 30 penting dalam memberikan kekasaran yang baik untuk kendaraan pada permukaan aspal.

2. Agregat halus pada ayakan no 30 sampai ayakan no 200 penting untuk menaikkan kadar aspal, akibatnya campuran akan lebih awet.

3. Keseimbangan proporsi penggunaan agregat kasar dan halus penting untuk memperoleh permukaan yang tidak licin dengan jumlah kadar aspal yang diinginkan (Darta Suhendra, 2013) 
Pemadatan Lapangan Asphalt Concrete Binder Course (AC-BC) pada Pembangunan Jalan Simpang Karya Mukti Kabupaten Batanghari

Tabel 3.Persyaratan Agregat Halus

\begin{tabular}{lcc}
\hline \multicolumn{1}{c}{ Pengujian } & Standar & Nilai \\
\hline Nilai Setara Pasir & SNI 03-4428-1997 & Min 60\% \\
Angularitas dengan Uji Kadar & SNI 03-6877-2002 & Min 45 \\
$\begin{array}{l}\text { Rongga } \\
\text { Gumpalan Lempung dan Butir-butir }\end{array}$ & SNI 03-4141-1996 & Maks 1\% \\
$\begin{array}{l}\text { Mudah Pecah dalam Agregat } \\
\text { Agregat Lolos Ayakan No.200 }\end{array}$ & SNI ASTM C117-2012 & Maks 10\% \\
\hline Sumber : Spesifikasi Umum Bina Marga & 2010 (Revisi 3) &
\end{tabular}

Bahan pengisi (filler) dapat mengunakan debu batu, kapur, semen portland, abu terbang, abu tanur semen atau material non plastis lainnya, asalkan bagian yang lolos saringan No. 200 sama atau lebih banyak dari $75 \%$ terhadap beratnya.

Menurut FR Yamali, 2013, dalam penelitiannya mengenai karakteristik aspal dilihat dari nilai yang didapat dibawah ini:

1. Nilai stabilitas pada peningkatan suhu pemadatan $120^{\circ} \mathrm{c}-150^{\circ} \mathrm{c}$ cenderung meningkat karena viskositas aspal rendah, sehingga proses pencampuran menjadi lebih baik dan didapat nilai stabilitas yang meningkat;

2. Nilai VMA pada peningkatan suhu pemadatan $120^{\circ} \mathrm{C}-150^{\circ} \mathrm{c}$ cenderung menurun hal ini disebabkan pemadatan pada suhu $120^{\circ} \mathrm{c}$ viskositas aspal tinggi, dan proses pemadatan tidak optimal dibanding pemadatan pada suhu $150^{\circ} \mathrm{C}$

3. Nilai flow pada suhu pemadatan $120^{\circ} \mathrm{c}$ sebesar $4,73 \mathrm{~mm}$, suhu pemadatan $130^{\circ} \mathrm{c}$ sebesar $5,00 \mathrm{~mm}$, suhu pemadatan $140^{\circ} \mathrm{c}$ flow sebesar $5,17 \mathrm{~mm}$, suhu pemadatan $150^{\circ} \mathrm{c}$ flow sebesar $5,27 \mathrm{~mm}$. nilai flow meningkat pada suhu pemadatan $150^{\circ} \mathrm{c}$ dikarenakan viskositas aspal rendah sehingga nilai kelelehan dalam campuran menjadi tinggi.

4. Nilai MQ pada suhu pemadatan $120^{\circ} \mathrm{c}$ sebesar $204,656 \mathrm{~kg} / \mathrm{mm}$, suhu pemadatan $130^{\circ} \mathrm{C}$ nilai MQ sebesar $231,883 \mathrm{~kg} / \mathrm{mm}$, suhu pemadatan $140^{\circ} \mathrm{C}$ nilai MQ sebesar $235,761 \mathrm{~kg} / \mathrm{mm}$, suhu pemadatan $150^{\circ} \mathrm{c}$ nilai MQ sebesar $237,104 \mathrm{~kg} / \mathrm{mm}$. nilai MQ naik pada suhu pemadatan $150^{\circ} \mathrm{c}$, disebabkan stabilitas naik pada suhu tersebut sehingga meningkatkan nilai kekakuan dari campuran perkerasan.

\section{METODE PENELITIAN}

Pembangunan Jalan Simpang Karya Mukti Kabupaten Batanghari terletak di Kecamatan Maro Sebo Ilir di Kabupaten Batanghari Provinsi Jambi.

\section{Acuan Operasionil Pekerjaan Campuran Beraspal Panas}

Proses pekerjaan campuran beraspal panas pada prinsipnya dimulai dari pembuatan Formula Campuran Kerja (FCK) / JMF (Job Mix Formula), kegiatan rutin di Unit Pencampur Aspal AMP (Asphalt Mixing Plant,) dan kemudian kegiatan penghamparan dan pemadatan di lapangan.

\section{Pembuatan Formula Campuran Kerja (FCK)}

Pembuatan formula campuran kerja, FCK (Job Mix Formula, JMF) meliputi tahapan pembuatan rancangan campuran berdasarkan agregat dari bin dingin (Cold Bins), pembuatan rancangan campuran berdasarkan agregat dari bin panas (Hot Bins), uji coba pencampuran di AMP, dan selanjutnya uji coba 
penghamparan dan pemadatan.Setelah semua tahapan tersebut dilaksanakan dan memenuhi persyaratan maka rancangan campuran dapat disahkan menjadi formula campuran kerja (JMF).Selama proses pembuatan formula campuran kerja (FCK / JMF), beberapa hal penting yang perlu mendapat perhatian adalah:

a. Bahan yang digunakan telah memenuhi syarat spesifikasi, perhatikan kepipihan dan kebersihan agregat yang digunakan.

b. Peralatan yang digunakan laik pakai, gunakan daftar periksa seperti yang dicantumkan pada Buku 3: Petunjuk umum, untuk pemeriksaan alat pemecah batu (stone crusher), unit pencampur aspal (AMP), dan alat penghampar (finisher).

c. Peralatan laboratorium yang digunakan harus memenuhi syarat, seperti dimensi dan kalibrasi.

\section{Penghamparan Campuran Beraspal}

Penghamparan campuran beraspal dilakukan dengan alat penghampar mekanis bermesin (finisher). Secara garis besar pemeriksaan yang dilakukan pada saat penghamparan adalah :

\section{Pemeriksaan kesiapan alat penghampar :}

1. Roda atau rantai baja (tracks) terpasang dengan baik. Tekanan roda yang kurang atau pemasangan rantai baja yang kurang kencang dapat mengganggu pergerakan finisher dan berakibat hasil penghamparan tidak merata.

2. Roda pendorong (push roller) harus bersih dan dapat berputar dengan baik sehingga truk dan alat penghampar dapat bergerak beriringan.

3. Penampung (hopper), sayap-sayap (wing hopper), penyalur (conveyor), pintu masukan penampung (flow gates), dan ulir pembagi (augers/screw) harus dapat bekerja dengan baik untuk menjaga kontinuitas aliran campuran beraspal. Kontinuitas aliran campuran beraspal yang terlalu sedikit atau berlebih dapat mempengaruhi tekstur dan keseragaman campuran.

4. Pelat sepatu (screed) harus dipanaskan pada awal operasi, untuk mencegah hasil penghamparan yang tampak kasar dan bertekstur terbuka.

5. Tinggi jatuh pemadat tumbuk dan pemilihan frekuensi penumbuk getar akan mempengaruhi tekstur permukaan yang diperoleh.

\section{Pemeriksaan campuran beraspal secara visual :}

1. Beberapa indikasi dari penyimpangan campuran beraspal dapat dilihat secara visual dan diperiksa sebelum dilakukan penghamparan, yaitu :

2. Berasap biru; asap biru yang keluar dari campuran berasapal di atas truk pengangkut atau terlihat pada pemasok (hopper) alat penghampar mengindikasikan terjadinya kelebihan panas (over heating).

3. Campuran beraspal tampak kaku; tampak visual campuran beraspal yang kaku mengindikasikan campuran tersebut telah dingin.

4. Permukaan campuran beraspal di atas bak truk tampak rata; pada umumnya permukaan campuran beraspal di atas bak truk membentuk bukit. Jika permukaan tersebut terlihat rata, maka kemungkinan campuran beraspal kelebihan aspal atau kadar air.

5. Campuran beraspal tampak kering / berwarna coklat; campuran yang mengandung terlalu sedikit aspal biasanya tampak kering dan berwarna kecoklatan. 
6. Campuran beraspal beruap; campuran beraspal masih mengandung kadar air. Kelebihan kadar air juga akan menyebabkan campuran beraspal terlihat seperti kelebihan aspal.

7. Segregasi; segregasi mungkin terjadi akibat kesalahan penanganan. Terkontaminasi; campuran beraspal dapat terkontaminasi solar yang disemprotkan pada dasar bak truk. Campuran beraspal juga dapat terkontaminasi plastik atau lainnya.

\section{Pemadatan Campuran Beraspal}

Pada saat pemadatan terjadi 3 gaya utama, yaitu gaya tekan alat pemadat, gaya tahan pada campuran beraspal yang baru dihampar, dan gaya tahan pada lapisan dibawahnya yang telah stabil (lapis pondasi agregat atau existing lapis beraspal). Untuk memperoleh pemadatan yang baik, maka gaya tahan lapisan yang telah stabil harus seimbang dengan gaya tekan alat pemadat. Atau dengan kata lain campuran beraspal seolah-olah mendapat gaya tekan dari atas dan bawah. Jika lapisan yang stabil (lapis pondasi agregat atau existing lapis beraspal) belum cukup padat maka kepadatan campuran beraspal kemungkinan tidak akan tercapai sesuai persyaratan.

\section{Alat pemadat}

a. Mesin gilas roda baja; digunakan untuk pemadatan awal (breakdown rolling ) atau pemadatan akhir (finish rolling). Untuk pemadatan akhir harus digunakan tandem dengan berat $8-10$ ton.

b. Mesin gilas roda karet penumatik ; digunakan untuk pemadatan antara (intermediate rolling). Alat pemadat ini merupakan alat pemadat utama dalam pemadatan campuran beraspal. Kepadatan diperoleh setelah berapa kali passing / lintasan sesuai dengan hasil uji coba pemadatan pada FCK (JMF).

\section{HASIL DAN PEMBAHASAN}

\section{Summary Of Design Mix FormulaAC-BC (DMF)}

Paling sedikit 30 hari sebelum dimulainya pekerjaan aspal di lapangan pelaksana harus menyerahkan secara tertulis kepada Direksi Pekerjaan usulan Design Mix FormulaAC-BC (DMF)

\section{Kalibrasi Bukaan Pintu Cold Bin}

Langkah awal untuk melakukan kegiatan di Instalasi Pencampur Asphal (Asphalt Mixing Plant, AMP) adalah melakukan Kalibrasi Bukaan Pintu Cold Bin agregat, agar jumlah agregat yang masuk ke Hot Bin sesuai dengan kebutuhan yang telah ditentukan. 
Pemadatan Lapangan Asphalt Concrete Binder Course (AC-BC) pada Pembangunan Jalan Simpang Karya Mukti Kabupaten Batanghari

Analisis dan Summary Bukaan Pintu Cold Bin

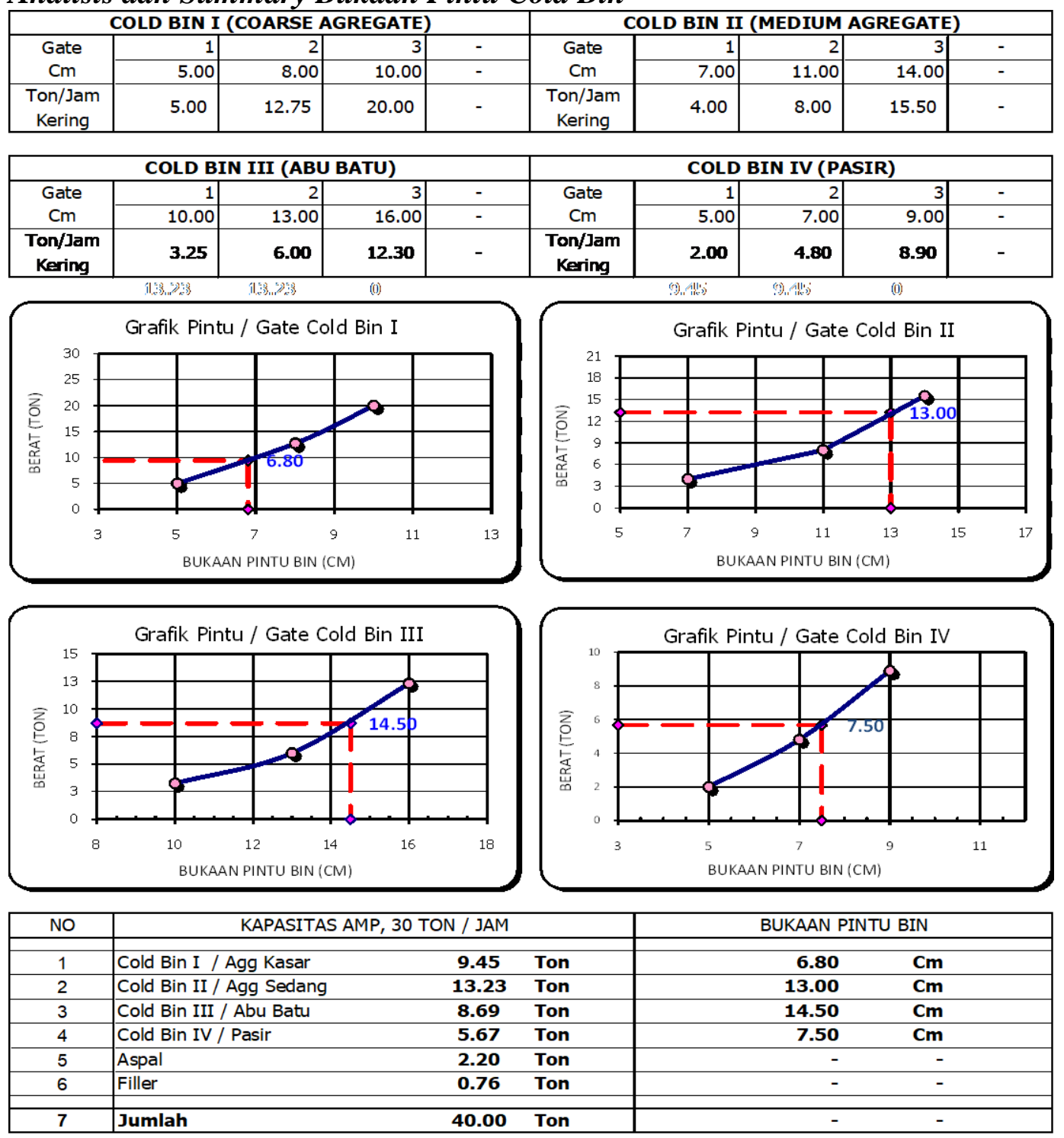

Sumber : Hasil Penelitian 2017

Berdasarkan hasil percobaan Hot Bin I, yang dilakukan nilai penyerapan rata-rata agregat halus $1.940 \%<5 \%$ dan berat jenis maksimum $2.514 \mathrm{gr} / \mathrm{cm} 3>$ $2.5 \mathrm{gr} / \mathrm{cm} 3$, hasil percobaan Hot Bin II yang didapat nilai penyerapan rata-rata agregat kasar $0.956 \%<3 \%$ dan berat jenis maksimum $2.524 \mathrm{gr} / \mathrm{cm} 3>2.5$ gr/cm3, dan berdasarkan hasil percobaan Hot Bin III didapat nilai penyerapan rata-rata agregat kasar $0.626 \%<3 \%$ dan berat jenis maksimum $2.590 \mathrm{gr} / \mathrm{cm} 3>$ $2.5 \mathrm{gr} / \mathrm{cm} 3$, maka agregat halus tersebut memenuhStandart Spesifikasi Umum Bina Marga 2010 (Revisi 3).Berdasarkan hasil percobaan dan pembahasan yang dilakukan didapat nilai penyerapan rata-rata agregat kasar $0.714 \%<3 \%$ dan berat jenis maksimum $2.602 \mathrm{gr} / \mathrm{cm} 3>2.5 \mathrm{gr} / \mathrm{cm} 3$, maka agregat halus tersebut memenuhStandart Spesifikasi Umum Bina Marga 2010 (Revisi 3).

Hasil didapat nilai keausan agregat sebesar $=18,24 \%$. Dimana nilai tersebut lebih kecil dari persyaratan yang telah ditentukan pada Spesifikasi Umun Bina Marga 2010 (Revisi 3) yaitu $=40 \%$. Setelah dilakukan percobaan pencampuran 
terlihat pada grafik gradasi gabungan masih ada dalam batas as atas dan ring bawah berarti memenuhi Standart Spesifikasi Umum Bina Marga 2010 (Revisi 3)

\section{Shetting Takaran Timbangan AMP di Lapangan}

Langkah berikutnya yang harus dilakukan di Instalasi Pencampur Asphal (Asphalt Mixing Plant, AMP) adalah melakukan settling Takaran Timbangan AMP, sehingga jumlah penggunaan material terukur dan hasil produksi dapat di kontrol dengan baik.

Setelah di adakan perhitungan dan pembahasan koefisien pemadatan rata-rata adalah $20 \%$ x $6 \mathrm{~cm}=1.2 \mathrm{~cm}$, maka total tebal gembur rata-rata $=6 \mathrm{~cm}+1.2 \mathrm{~cm}$ $=7.2 \mathrm{~cm}$

\section{Kepadatan Lapangan Hasil Core}

Tabel 4. Kepadatan Lapangan Hasil Core

\begin{tabular}{|c|c|c|c|c|c|c|c|c|c|c|}
\hline \multirow[b]{2}{*}{ NO } & \multirow[b]{2}{*}{ STATION } & \multirow[b]{2}{*}{$\mathrm{L} / \mathrm{R}$} & \multirow[b]{2}{*}{$\begin{array}{c}\text { KETEBALA } \\
\text { N CORE } \\
\text { (CM) }\end{array}$} & \multicolumn{3}{|c|}{ BERAT CONTOH } & \multirow{2}{*}{$\begin{array}{c}\text { ISI } \\
\text { BENDA } \\
\text { UJI }\end{array}$} & \multirow{2}{*}{$\begin{array}{c}\text { BD } \\
\text { HASIL } \\
\text { CORE }\end{array}$} & \multirow[b]{2}{*}{$\begin{array}{c}\text { BD BULK } \\
\text { CAMPUR } \\
\text { AN }\end{array}$} & \multirow{2}{*}{$\begin{array}{c}\text { DERAJAT } \\
\text { KEPADAT } \\
\text { AN } \\
(\%)\end{array}$} \\
\hline & & & & $\begin{array}{c}\text { DI } \\
\text { UDARA }\end{array}$ & $\begin{array}{l}\text { DALAM } \\
\text { AIR }\end{array}$ & $\begin{array}{c}\text { KERING } \\
\text { PERMUKA } \\
\text { AN } \\
\end{array}$ & & & & \\
\hline \multicolumn{11}{|c|}{ VARIASI I (SATU) STA : 1+050 $\sim 1+075$ L (PASSING $2 ; 12 ; 2)$} \\
\hline & & & & $\mathbf{a}$ & b & c & $\mathbf{d}=\mathbf{( - \mathbf { c } )}$ & $e=(\mathbf{a} / \mathbf{d})$ & F(JME) & $\mathbf{g}=(\mathbf{e} / \mathbf{f})$ \\
\hline \multirow[t]{3}{*}{1} & 01+062 & $\mathbf{L 1}$ & 6.50 & $1,143.5$ & 636.3 & $1,146.6$ & 510.3 & 2.241 & 2.289 & $97 \_90$ \\
\hline & & $\mathbf{L} 2$ & 6.30 & $1,120.7$ & 629.2 & $1,123.8$ & 494.6 & 2.266 & 2.289 & 99.00 \\
\hline & RATA2 & & 6.40 & & & & & & & 98.45 \\
\hline \multicolumn{11}{|c|}{ VARIASI II (DUA) STA : 1+075 1+100 L (PASSING $2 ; 14 ; 2)$} \\
\hline & & & & a & b & c & $\mathbf{d}=(\mathbf{c}-\mathbf{b})$ & $\mathbf{e}=(\mathbf{a} / \mathbf{d})$ & f (JMF) & $\mathbf{g}=(\mathbf{e} / \mathbf{f})$ \\
\hline \multirow[t]{3}{*}{2} & $01+085$ & L1 & 6.10 & $1,095.1$ & 619.4 & $1,098.2$ & 478.9 & 2.287 & 2.289 & 99.91 \\
\hline & & L2 & 6.00 & $1,076.7$ & 608.8 & $1,079.8$ & 471.0 & 2.286 & 2.289 & 99.87 \\
\hline & RATA2 & & 6.05 & & & & & & & 99.89 \\
\hline \multicolumn{11}{|c|}{ VARIASI III (TIGA) STA : 1+050 $\sim 1+100$ R (PASSING $2 ; 16 ; 2)$} \\
\hline & & & & $\mathbf{a}$ & b & c & $\mathbf{d}=\mathbf{(}-\mathbf{b})$ & $e=(\mathbf{a} / \mathbf{d})$ & F (JME) & $\mathbf{g}=(\mathbf{e} / \mathbf{f})$ \\
\hline \multirow[t]{4}{*}{3} & $01+075$ & R1 & 5.80 & $1,040 \_4$ & 588.2 & $1,043 \ldots$ & 455.3 & 2.285 & 2.289 & 99.83 \\
\hline & & $\mathbf{R 2}$ & 5.90 & $1,059.7$ & 599.6 & $1,062.8$ & 463.2 & 2.288 & 2.289 & 99.96 \\
\hline & RATA2 & & 5.85 & & & & & & & 99.89 \\
\hline & & & & & & & & & & \\
\hline
\end{tabular}

Sumber: Hasil perhitungan lapangan, 2017

Setelah selesai dilakukan percobaan pemadatan lapangan dengan 3 (tiga) variasi, ternyata berdasarkan hasil yang paling memenuhi Standar Spesifikasi Umum Bina Marga 2010 (Revisi 3) adalah percobaan variasi II dimana tebal core rata-rata $6.05 \mathrm{~cm}>6.00 \mathrm{~cm}$ dan nilai derajat kepadatan rata-rata $99.89 \%>98 \%$, maka untuk melaksanakan pekerjaan pemadatan lapangan selanjutnya berpedoman pada variasi II yaitu pemadatan awal 2 passing Tandem Roller (8 Ton) dengan suhu $125^{\circ} \mathrm{C}$, pemadatan antara 14 passing Pneumatic Tire Roller (12 Ton) dengan suhu $100^{\circ} \mathrm{C}$ dan pemadatan akhir 2 passing Tandem Roller (8 Ton) dengan suhu $95^{\circ} \mathrm{C}$.

Setelah dilaksanakan Trial Mix \& Compaction di lapangan dan hasilnya memenuhi persyaratan yang telah ditetakan Spesifikasi Umum Bina Marga 2010 (Revisi 3), Maka Job Mix Formula Resmi ditetapkan sebagai pedoman pelaksanaan pekerjaan 


\section{SIMPULAN}

1. Nilai koefisien pemadatan (faktor gembur) hamparan dilapangan Asphalt Concrete Binder Course (AC-BC) adalah $20 \%$ dari tebal padat $6 \mathrm{Cm}=1.20$ $\mathrm{Cm}$, maka total hamparan gembur $6.00 \mathrm{Cm}+1.20 \mathrm{Cm}=7.20 \mathrm{Cm}$.

2. Jumlah passing/lintasan dan temperatur serta jenis alat yang dipakai pada pemadatan awal, pemadatan antara dan pemadatan akhir adalah berpedoman pada percobaan variasi II yaitu pemadatan awal 2 passing Tandem Roller $(8$ Ton) dengan suhu $125^{\circ} \mathrm{C}$, pemadatan antara 14 passing Pneumatic Tire Roller(12 Ton) dengan suhu $100^{\circ} \mathrm{C}$ dan pemadatan akhir 2 passing Tandem Roller(8 Ton) dengan suhu $95^{\circ} \mathrm{C}$.

3. Setelah dilakukan core tebal yang didapat adalah $6.05 \mathrm{Cm}>6.00 \mathrm{Cm}$ dan nilai derajat kepadatan adalah $99.89 \%>89.00 \%$.

\section{Saran}

1. Pentingnya Trial Mix dan Inspection Lapangan dilakukan oleh Pelaksana Kegiatan (Owneer, kontraktor dan konsultan supervisi) sebelum memulai melaksanakan pekerjaan.

2. Setiap melaksanakan pekerjaan Asphalt Concrete Binder Course (AC-BC) harus benar-benar berpedoman pada hasil Trial Mix dan Inspection Lapangan

3. Untuk menghilangkan bekas jejak roda Pneumatic Tire Roller sebaiknya Finishing Compact harus dilaksanakan.

4. Temperatur / Suhu Hotmix mulai dari penghamparan sampai dengan Finishing Compact harus selalu dikontrol dengan baik.

\section{DAFTAR PUSTAKA}

Darta Suhendra, 2013 "Pengaruh Variasi Temperatur Pada Proses Pencampuran Terhadap Campuran Aspal Panas (Asphal Hotmix) " Universitas Lampung

Departemen Permukiman Dan Prasana Wilayah, 2002 "Manual Pekerjaan Campuran Beraspal Panas" Direktorat Jendral Prasana Wilayah, Jakarta.

Hendarsin, Shirley L, 2000 "Perencanaan Teknik Jalan Raya" Jurusan Teknik Sipil-Politeknik Negeri Bandung, Bandung.

Kementerian Pekerjaan Umum, 2010 "Spesifikasi Umum Bina Marga(Revisi 3)" Direktorat Jendral Bina Marga Direktorat Bina Teknik, Jakarta.

PT. Abun Sendi, 2016 “Job Mix Formula Laston Lapis Antara (AC-BC)” Paket Pembangunan Jalan Sp. Karya Mukti - Ds. Karya Mukti, Muara Bulian.

Sukirman, Silvia, 1999 "Perkerasan Lentur Jalan Raya” Bandung : Nova.

SNI 03-1968-1990, 1990 "Metode Pengujian Tentang Analisa Saringan Agregat Halus dan Kasar” Badan Standardisasi Nasional (BSN).

SNI 03-1970-1990, 1990 "Metode Pengujian Berat Jenis dan Penyerapan Air Agregat Halus dan Kasar” Badan Standardisasi Nasional (BSN).

SNI 03-1737-1989, 1989 "Tata cara Pelaksanaan Lapis Aspal Beton (Laston) untuk Jalan Raya” Badan Standardisasi Nasional (BSN).

SNI 03-2417-2008, 2008 "Cara Uji Keausan Agregat dengan Mesin Abrasi Los Angeles" Badan Standardisasi Nasional (BSN).

Yamali FR, 2013, "Kombinasi Ukuran Agregat Kasar Terhadap Campuran Asphalt Concreate-Binder Course (AC-BC)" Journal Ilmiah, Vol. 13 No. 3, Universitas Batanghari Jambi, ISSN 1411-8939 
Pemadatan Lapangan Asphalt Concrete Binder Course (AC-BC) pada Pembangunan Jalan Simpang Karya Mukti Kabupaten Batanghari

Yamali FR, 2013, "Pengaruh Variasi Suhu Pemadatan Terhadap Karakteristik Campuran Split Mastic Asphalt 0/11” Journal Teknik Sipil, Vol. 2 No. 3, Universitas Syiah Kuala Banda Aceh,ISSN 2088-9321. 